Marquette University

e-Publications@Marquette

Theology Faculty Research and Publications

Theology, Department of

$1-1-2005$

Valuing Earth Intrinsically and Instrumentally: A Theological Framework for Environmental Ethics

Jame Schaefer

Marquette University, jame.schaefer@marquette.edu

Published version. Theological Studies, Vol. 66, No. 4 (2005): 783-814. Publisher link. (C) 2005

Theological Studies, Inc. Used with permission. 


\title{
VALUING EARTH INTRINSICALLY AND INSTRUMENTALLY: A THEOLOGICAL FRAMEWORK FOR ENVIRONMENTAL ETHICS
}

\author{
JAME SCHAEFER
}

\begin{abstract}
[Philosophers have struggled with value theory as one of the most recalcitrant problems for environmental ethics. Theologians can benefit from their efforts when retrieving and reworking notions about the goodness of creation in patristic and medieval texts, particularly those by Augustine, John Chrysostom, and Thomas Aquinas. This process yields a religiously motivated rationale for intrinsic-instrumental valuing of the physical world's constituents for themselves, their relationships to one another, and their common good that can be relevant, meaningful, and helpful for responding to ecological degradation.]
\end{abstract}

$\mathrm{S}$ INCE THE INCEPTION of environmental philosophy as an academic field, scholars have struggled to construct an adequate theory of valuing other species, ecological systems, and the greater biosphere. J. Baird Callicott, a major contributor to this effort, has identified value theory as the "central and most recalcitrant problem" for environmental ethics. ${ }^{1}$ Among the important questions with which philosophers have grappled are: (1) Should other-than-humans be valued instrumentally as means to human

JAME SCHAEFER received her Ph.D. in religious studies at Marquette University where she is now assistant professor in systematic theology and ethics, as well as the director of an interdisciplinary minor in environmental ethics. Recent publications reflect her concentration on theology and the natural sciences: "Reporting Complexity: Science and Religion," in Quoting God: How Media Shape Ideas about Religion and Culture, ed. Claire Badaracco (Baylor University Press, 2005), and "Environmental Ethics from an Interdisciplinary Perspective," Worldviews: Environment, Culture, Religion (Fall 2004). In addition to the texts of several forthcoming lectures, she is also preparing a monograph entitled Catholic Foundations for Environmental Ethics (Catholic University of America Press).

${ }^{1} \mathrm{~J}$. Baird Callicott, "Intrinsic Value, Quantum Theory, and Environmental Ethics," Environmental Ethics 7 (1985) 257-75, at 257. Fifteen years later, he repeated this lament: "The intrinsic-value-in-nature question has been, and remains, the central and most persistent cluster of problems in theoretical environmental philosophy" ("Introduction" to Beyond the Land Ethic: More Essays in Environmental Philosophy [Albany: State University of New York, 1999] 15). 
ends, as Bryan Norton insists ${ }^{2}$ or intrinsically as ends in themselves, as Callicott, Holmes Rolston III, Arne Naess, and others argue $?^{3}$ (2) If nonhuman entities are valued intrinsically, does their value originate and persist in them to be discovered by humans, as Rolston argues, ${ }^{4}$ or is value something that humans create and attribute to other-than-humans, as Callicott proffers? $?^{5}$ (3) Is one ethic or set of ethics capable of adjudicating

${ }^{2}$ Bryan G. Norton argues that "an adequate environmental ethic need not be non-anthropocentric and that an adequate environmental ethics must not be limited to considerations of individual interests" ("Environmental Ethics and Weak Anthropocentrism," Environmental Ethics 6 [1984] 131-48, at 141). Also see Norton, "Why I am Not a Nonanthropocentrist: Callicott and the Failure of Monistic Inherentism," Environmental Ethics 17 (1995) 341-58, in which he counters Callicott's ecologically centered approach as "especially damaging to the cause of a practical environmental philosophy-one that could contribute to real world policy discussions and environmental problem solving" and argues for abandoning the concept of intrinsic value altogether. In "Intrinsic Value for Pragmatists," Environmental Ethics 22 (Spring 2001) 57-75, Ben A. Minteer staunchly defends Norton's pragmatism while Laura Westra explains "Why Norton's Approach is Insufficient for Environmental Ethics," Environmental Ethics 19 (1997) 279-97.

${ }^{3}$ For example, see Callicott, "On the Intrinsic Value of Nonhuman Species," in The Preservation of Species, ed. Bryan G. Norton (Princeton: Princeton University, 1986) 138-72 and "Intrinsic Value in Nature: A Metaethical Analysis," Electronic Journal of Analytical Philosophy 3 (Spring 1995) www.phil.indiana.edu/ejap/ 1995.spring/callicott.abs.html (reprinted in Beyond the Land Ethic: More Essays in Environmental Philosophy, ed. Callicott [Albany: State University of New York, 1999] 236-61); Holmes Rolston III, "Intrinsic Value in Nature: A Metaethical Analysis," in Environmental Ethics: Duties to and Values in Nature, ed. Rolston (Philadelphia: Temple University, 1988); Arne Naess, "A Defense of the Deep Ecology Movement," Environmental Ethics 6 (1984) 265-70; Robert Elliot, "Intrinsic Value, Environmental Obligation and Naturalism," The Monist 75 (1992) 138-60; and Eugene C. Hargrove, "Weak Anthropocentric Intrinsic Value," The Monist 75 (1992) 183-212.

${ }^{4}$ Holmes Rolston III proffers this position: "To say that something is valuable means that it is able to be valued, if and when (human) valuers come along, but it has this property whether or not humans (or other valuers) ever arrive" (Environmental Ethics: Duties to and Values in Nature [Philadelphia: Temple University, 1988] 114). Also see Rolston, "Value in Nature and the Value of Nature," in Environmental Ethics: An Anthology (Malden, Mass.: Blackwell, 2003) 143-53 where he argues that value in the natural world preexists humans, is located in individuals, species, ecosystems and evolutionary processes, and would exist if humans were to become extinct. See further his chapter entitled "Are Values in Nature Subjective or Objective?" in his collection of essays in Philosophy Gone Wild (Buffalo: Prometheus, 1989). Also see "The Varieties of Intrinsic Value," The Monist 75 (1992) 119-37 in which John O'Neill explores three interchangeable ways in which "intrinsic value" is used.

${ }^{5}$ According to J. Baird Callicott, In Defense of the Land Ethic: Essays in Environmental Philosophy (Albany: State University of New York, 1989) 133-34, values 
conflicts among valued beings, or is a plurality of diverse ethical systems required ${ }^{6}$ As Claire Palmer explains, each of these questions raises others while scholars work toward cogent ways of thinking about valuing other species, ecological systems, and the larger biosphere. ${ }^{7}$

Theologians can benefit from philosophers' identification and refinement of issues pertaining to the value of other-than-human entities that constitute Earth. Philosophical efforts can be particularly helpful to scholars of the world's religions who are striving to develop systematic ways of addressing ecological issues from the data of their various traditions.

A particularly fruitful notion to explore in the Christian tradition is the goodness of creation. As demonstrated in this article, thinking about the physical world's goodness is deeply embedded in patristic and medieval texts by some of Christianity's eminent theologians, including Augustine of Hippo (354-430 A.D.), John Chrysostom (347-407), and Thomas Aquinas (1225?-1274). They suggest a theologically based theory of valuing from which broad behavioral norms can be discerned and subsequently reworked to reflect our current understanding of the world. From this process emerges a religiously motivated rationale for intrinsic-instrumental valuing of the physical world's constituents for themselves, for their relationships to one another, and for their common good. This valuation can be

depend upon human judgment and, therefore, are subjective. See also his "On the Intrinsic Value of Nonhuman Species," in The Preservation of Species, ed. Bryan G. Norton (Princeton: Princeton University, 1986) 138-72, at 142-43, where he argues that the "source of all value is human consciousness ... since no value can in principle ... be altogether independent of a valuing consciousness." Value is "projected onto natural objects or events by the subjective feelings of observers. If all consciousness were annihilated at a stroke, there would be no good and evil, no beauty and ugliness, no right and wrong; only impassive phenomena would remain." Eugene C. Hargrove counters this classification of valuing in "Weak Anthropocentric Intrinsic Value," The Monist 75 (1992) 183-207; Hargrove judges Callicott's position as "overly subjective" in part because some values are the product of cultural evolution that serve as foundations for individuals.

${ }^{6}$ See J. Baird Callicott, "Moral Monism in Environmental Ethics Defended," Journal of Philosophical Research 90 (1994) 51-60; also his "The Case Against Moral Pluralism," Environmental Ethics 12 (1990) 99-124. The use of several systems of ethics to address a range of moral problems is championed by Christopher Stone in Earth and Other Ethics: The Case for Moral Pluralism (New York: Harper \& Row, 1987) and in "Moral Pluralism and the Course of Environmental Ethics," Environmental Ethics 10 (1988) 139-54.

${ }^{7}$ Palmer identifies and summarizes these questions astutely with references to pertinent environmental philosophers. See "An Overview of Environmental Ethics," in Environmental Ethics: An Anthology, ed. Andrew Light and Holmes Rolston III (Malden, Mass.: Blackwell, 2003) 15-37. A cursory search of the scholarly literature yields a plethora of articles, anthologies, and monographs on the subject, including an entire issue of The Monist 75 (1992). 
realistic, relevant, and meaningful for Christians who believe that the ultimate bestower of value is God.

In this article, I begin by exploring various teachings about the goodness of creation in representative texts by Augustine, Chrysostom, and Aquinas, focusing on the goodness of natural beings, gradations of goodness among creatures, the greater goodness of the totality of creation, its common good, God's valuation of creation, and human valuing. Principles of these teachings that appear promising for addressing ecological degradation are identified, updated to reflect our current understanding of the world, compared with parallel issues that secular philosophers have been addressing, and applied to the Everglades ecological system. I conclude with the five basic behavioral norms that constitute the ethics of intrinsic-instrumental valuing.

\section{THE GOODNESS OF CREATION}

Throughout the patristic and medieval periods, Christian theologians taught that God created the universe of many diverse animate and inanimate beings, they are all good, they altogether comprise a superlative goodness, and they are valued by God. The context of their teachings and the nuances of their reflections varied as some theologians responded to heresies of their times, others commented on the first but more recent of the two stories of creation that appear in Genesis, ${ }^{8}$ and a few wove their understanding of the goodness of creation into systematic treatments of God's relationship to the world. All shared a faith perspective that is profoundly monotheistic: God is the creator of all natural beings that constitute the universe; each animate and inanimate being has a God-given purpose; the entire universe is utterly dependent upon God for its existence; and, humans are responsible to God for how they function in the world.

\section{The Goodness of Natural Beings}

For Augustine of Hippo, nothing exists that does not derive its existence from God, the "supremely good Creator"" who created ex nihilo the uni-

\footnotetext{
${ }^{8}$ Bernard W. Anderson, From Creation to New Creation: Old Testament Perspectives (Minneapolis: Fortress, 1994).

${ }^{9}$ Augustine, The Enchiridion: On Faith, Hope, and Love, trans. J. F. Shaw, ed. Henry Paolucci (Chicago: Regnery Gateway, 1961) 10.10 (hereafter cited as Enchiridion). See also Augustine's The Nature of the Good Against the Manichees (De Natura Boni) in Augustine: Earlier Writings, trans. and ed. J. H. S. Burleigh, Library of Christian Classics (Philadelphia: Westminster, 1953) 1.326 (hereafter cited as Nature of the Good). He continues in Enchiridion 10: "By the trinity, thus supremely and equally and unchangeably good, all things were created; and these are not supremely and equally and unchangeably good, but yet they are good, even taken separately."
} 
verse of "good things, both great and small, celestial and terrestrial, spiritual and corporeal." ${ }^{10}$ Some people do not understand that every natural being is good, he wrote against his former companions, the Manichees, but "Catholic Christians" recognize that there are "generic good things to be found in all that God has created, whether spirit or body." Comparing the body of a human with the body of an ape, he concluded that each has its own characteristics according to its nature and, accordingly, both are good. ${ }^{12}$ The expansiveness of his valuation is exemplified in The Trinity where he declared:

[T]he earth is good by the height of its mountains, the moderate elevation of its hills, and the evenness of its fields; and good is the farm that is pleasant and fertile; and good is the house that is arranged throughout in symmetrical proportions and is spacious and bright; and good are the animals, animate bodies; and good is the mild and salubrious air; and good is the food that is pleasant and conducive to health; and good is health without pains and weariness; and good is the countenance of man with regular features, a cheerful expression, and a glowing color; and good is the soul of a friend with the sweetness of concord and the fidelity of love; and good is the just man; and good are riches because they readily assist us; and good is the heaven with its own sun, moon, and stars. ${ }^{13}$

Even if a body is diminished and loses its beauty, it is good, he insisted, because it exists. ${ }^{14}$

Reflecting on Genesis 1, Chrysostom dwelt on the inspired author's depiction of God's valuing each type of creature as "good." When God declared that creatures are good, the gifted preacher argued, "who would dare, even if bursting with arrogant folly, to open his mouth and gainsay the words uttered by God?" He identified creatures that are both beneficial and harmful to humans:

Among the growth springing up from the earth it was not only plants that are useful but also those that are harmful, and not only trees that bear fruit but also those that bear none; and not only tame animals but also wild and unruly ones. Among the creatures emerging from the waters it was not only fish but also sea monsters and

${ }^{10}$ Augustine, Nature of the Good 3.326.

${ }^{11}$ Ibid. 3.327.

${ }^{12}$ Ibid. 14.330; see also $17.330-31$.

${ }^{13}$ Augustine, The Trinity, trans. Stephen McKenna, C.SS.R. (Washington: Catholic University of America, 1963) 8.247-52.

${ }^{14}$ Augustine, Nature of the Good 4.327; 15 and 17.330 where he used the concepts of goodness and existence interchangeably. In Nature of the Good 6.328, he wrote: "[A]ny nature which can be corrupted has some good in it, for corruption could not harm it except by taking away or diminishing what is good in it." He continued his thinking in The Confessions of St. Augustine, trans. John K. Ryan (Garden City: Image, 1960) 7, chap. 12.18 (hereafter cited as Confessions) that those who are suffering corruption are nevertheless good, while beings deprived of all good cease to exist. 
other fierce creatures. It was not only inhabited land but also the unpeopled; not only level plains but also mountains and woods. Among birds it was not only tame ones and those suitable for our food but also wild and unclean ones, hawks and vultures and many others of that kind. Among the creatures produced from the earth it was not only tame animals but also snakes, vipers, serpents, lions and leopards. In the sky it was not only showers and kindly breezes but also hail and snow. ${ }^{15}$

According to Chrysostom, anyone who found fault with these creatures or inquired in any disparaging way about their purpose or use would be showing ingratitude to their Creator. ${ }^{16}$

Aquinas consistently stressed the goodness of the physical world, as Josef Pieper and others have aptly demonstrated. ${ }^{17}$ Like Augustine, Aquinas pointed to the story of creation in Genesis 1 to affirm the goodness of each type of creature, ${ }^{18}$ and he reasoned to their goodness from their existence which he attributed ultimately to God. ${ }^{19}$ Going beyond

${ }^{15}$ Saint John Chrysostom, Homilies on Genesis 1-17, trans. Robert C. Hill, Fathers of the Church 74 (Washington: Catholic University of America, 1986) Homily 10.12, 135-37.

16 Ibid.

${ }^{17}$ Joseph Piper, "Of the Goodness of the World," Orate Fratres 25 (1951) 433-37. According to Piper, Aquinas's summation omne ens est bonum is "the deepest, profoundest meaning and root of all those sentences is that every being as being is intended and even loved by the Creator, that every creature at the same time receives its being-real and its being-loved" (433-34). On initial ethical implications of Aquinas's thinking about the goodness of creatures in relation to the physical environment, Jean Porter contends astutely that the legitimacy of humanity's use of "the subhuman creation" for its own well-being would have to be acknowledged if the thomistic framework of thinking were brought to bear on the ecological crisis. She cautions, however, that the right to use other created things does not mean that humans may treat the rest of corporeal creation in any way they desire, and she offers two parameters from Aquinas's thinking within which the human use of creation would fall: (1) Any use of the rest of the created world would have to be directed to the good of all humanity; and, (2) all created things possess "an intrinsic goodness apart from their potential usefulness to anything else" which requires "some form of respect" (The Recovery of Virtue: The Relevance of Aquinas for Christian Ethics [Louisville: Westminster/John Knox, 1990] 178). Also see James F. Keenan, "Goodness and Rightness in Aquinas's Summa Theologiae," The Thomist 58 (1994) 342-48.

${ }^{18}$ St. Thomas Aquinas, Summa Theologiae, trans. by English Dominicans (London: Burns, Oates, and Washbourne, 1912-36; repr. New York: Benziger 1947-48; repr. New York: Christian Classics, 1981), in The Collected Works of St. Thomas Aquinas, Past Masters Electronic Resource (Charlottesville, Virg.: InteLex, 1993) 1 , q. 47 , a. 2.

${ }^{19}$ For example, see St. Thomas Aquinas, Summa Contra Gentiles, trans. English Dominicans (London: Burns, Oates, and Washbourne, 1934) in The Collected Works of St. Thomas Aquinas, Past Masters Electronic Resource (Charlottesville, Virg.: InteLex, 1993) 3, chap. 7; and Summa theologiae 1, q. 60, a. 1, ad 3. 
Augustine's interchange of goodness and existence, Aquinas depicted each entity as perfect in some innate way specified by God. Each is endowed with a way of existing and, if animate, a way of acting according to its nature. To criticize a creature's nature or its natural inclination is, he insisted, an insult to the Creator of nature. ${ }^{20}$

For Aquinas, another dimension of goodness is its likeness to God's goodness through its innate way of existing as determined by God. ${ }^{21}$ The human is distinct among creatures, however, since the human also bears an image of God through the ability to comprehend. ${ }^{22}$ Only the intellectual aspects of the human bear God's image, however, while the nonintellectual aspects of the physical body retain only a likeness of God's goodness by its existence. $^{23}$

Augustine, Chrysostom, and Aquinas ascribed to the intrinsic valuing of all types of creatures as distinct entities that are essential to the world. As Kavanaugh notes from Aquinas's thinking, this intrinsic goodness and value persists regardless of its role as a function of human happiness. ${ }^{24}$ Creatures are not islands in the scheme of the world's functioning accord-

${ }^{20}$ Aquinas, Summa theologiae 1, q. 60, a. 1, ad 3; see further 1, q. 103, a. 7, ad 1; 2-2, q. 23, a. 8, and q. 47, a. 1, ad 1. Also see Saint Thomas Aquinas, On Charity (De Caritate), trans. Lottie H. Kendzierski (Milwaukee: Marquette University, 1960) in The Collected Works of St. Thomas Aquinas, Past Masters Electronic Resource (Charlottesville, Virg.: InteLex, 1993) 3 (hereafter cited as On Charity); Summa contra gentiles 3, chap.12; and The Disputed Questions on Truth, trans. James V. McGlynn, S.J., in The Collected Works of St. Thomas Aquinas, Past Masters Electronic Resource (Charlottesville, Virg.: InteLex, 1993) 2, q. 16, a. 2 (hereafter cited as On Truth).

${ }^{21}$ Aquinas, Summa contra gentiles 2 , chap. 46 . That a created being achieves a participated likeness of the divine also surfaces in St. Thomas Aquinas, Compendium of Theology, trans. Cyril Vollert (St. Louis: Herder, 1947) in The Collected Works of St. Thomas Aquinas, Past Masters Electronic Resource (Charlottesville, Virg.: InteLex, 1993) 103 (hereafter cited as Compendium of Theology) where he explains that the divine goodness is not only the end of the creature but is also the end of every operation of any creature insofar as each has some participated likeness to the divine goodness. See further Summa theologiae 1, q. 44, a. 4.

${ }^{22}$ Aquinas, Compendium of Theology 75. Also see Summa theologiae 1, q. 93, a. 2; and Summa contra gentiles 2, chap. 46.

${ }^{23}$ Aquinas, Summa theologiae 1, q. 93, a. 6. Also see Summa contra gentiles 3, chap. 2. Aquinas considered creatures' likeness to God within a trinitarian framework. Following Augustine in The Trinity 6, chap.10, he found a likeness of the Trinity by way of a trace in all creatures insofar as they are caused by the divine persons. In Summa theologiae 1, q. 45, a. 7, he taught that the creature represents the person of the Father as its cause, the person of the Word as the form conceived, and the person of the Holy Spirit as loved and willed to be.

${ }^{24}$ John F. Kavanaugh, S.J., "Intrinsic Value, Persons and Stewardship," in The Challenge of Global Stewardship: Roman Catholic Responses, ed. Maura A. Ryan and Todd David Whitmore (Notre Dame: University of Notre Dame, 1997) 67-81. 
ing to these three representative theologians. Inherent in their teachings is an understanding that creatures are related to one another, to the universe as a totality, and to God.

\section{Grades of Goodness among Creatures}

While patristic and medieval theologians taught that all creatures are good and valuable, they also stated that creatures vary in the extent of their goodness and value. This variability accords with their innate makeup and ways of existing. Augustine exclaimed that God did not make "all things equal" since the level of the goodness of creatures depends upon their "measure, form and order." 25 Some creatures are superior to others pursuant to their innate characteristics, and rational creatures are God's most excellent creatures because God gives them the power to avoid willing corruption out of obedience to God. ${ }^{26}$

Aquinas reasoned to degrees of goodness among creatures. Arguing against some philosophers' explanations for the differences among creatures, he insisted that their characteristics are attributable only to God who created and, thereby, communicated various "grades of goodness" to them. ${ }^{27}$ Building upon Aristotle's observations, Aquinas envisioned a simplistic hierarchical arrangement of diverse and unequal entities in which some have greater degrees of goodness than others according to their innate capabilities and complexities: mixed elements that are more perfect than the primary elements (air, water, fire, and earth), plants than minerals, animals than plants, and humans than other animals. ${ }^{28} \mathrm{He}$ occasionally referred to this arrangement as an "order of conservation" in which the higher relied upon the lower for sustenance. ${ }^{29}$ Thus, mixed bodies rely

${ }^{25}$ Augustine, Confessions 7, chap. 12.18. Also see Augustine's Concerning the City of God against the Pagans, trans. Henry Bettenson, intro. John O'Meara (London: Penguin, 1984) 11, chap. 22 (hereafter cited as City of God) for Augustine's theocentric theory about the need for inequality in the universe.

${ }^{26}$ Augustine, Confessions 13, chap. 32.47.

${ }^{27}$ Aquinas, Summa theologiae 1, q. 48, a. 2. See also Summa contra gentiles 3, chap. 20. Among the many other references to God's having created many grades of good entities and ordering them to one another for the perfection of the universe are Summa theologiae 1, q. 65, a. 3; Summa contra gentiles 2, chap. 4. and 3, chap. 71; and Compendium of Theology 73.

${ }^{28}$ Aquinas, Summa theologiae 1, q. 47, a. 2 is one of many examples of Aquinas's teachings about the instrumental order of all beings that constitute the universe. That everything God created has a purpose to fulfill in the integral whole and all are related to one another in a hierarchical order to achieve their purposes as well as the purpose of the whole cosmos was constant in Aquinas's writings. Also see Summa contra gentiles 3, chap. 20,45, and 71 .

${ }^{29}$ Aquinas, Summa contra gentiles 3, chap. 22. See also Summa theologiae 2-2, q. 66 , a. 2. 
upon the elements, plants upon mixed bodies, animals upon plants, and humans upon animals and plants to sustain their physical needs. ${ }^{30}$ While the higher type of creature is considered more valuable than the lower, primarily because of the higher's innate capabilities, each is essential for the functioning of the universe and is, therefore, valuable. The lower and less capable exist for the sake of the next higher type of being in the hierarchy, he reasoned from his medieval understanding of the world, and all are needed to internally maintain the universe. ${ }^{31}$ Thus, all grades of goodness are essential to its perfection. ${ }^{32}$

Addressing the role of humans in this hierarchy of beings, Aquinas explained that humans have the highest degree of goodness among physical creatures because humans can embrace and transcend the corporeal world $^{33}$ through their ability to reflect on what is stored in their memory, to choose to act according to the dictates of reason, ${ }^{34}$ and to cooperate with God's grace in seeking eternal happiness with God. ${ }^{35}$ Humans use other creatures in two ways during their temporal lives: (1) as instruments or

${ }^{30}$ Ibid.

${ }^{31}$ Aquinas, Summa theologiae 1, q. 65, a. 2. Each creature exists for its own proper act and perfection, the lower on the hierarchical scale exists for the higher, while every creature exists for the perfection of the universe that is ordered toward God inasmuch as it imitates and shows forth the Divine goodness to the glory of God.

${ }^{32}$ Aquinas, Summa theologiae 1, q. 47, a. 2; he alluded to Aristotle's Metaphysics 8.10 when describing this hierarchical configuration. The concept of a hierarchy of beings has its basis in Greek philosophy, flourished in the patristic and medieval periods, and is the subject of a lecture given by Arthur Q. Lovejoy in 1933 which was published subsequently as The Great Chain of Being: A Study of the History of an Idea (Cambridge, Mass.: Harvard University, 1957). Aquinas's understanding of the hierarchical chain is highly organic.

${ }^{33}$ Aquinas, Summa theologiae 1, q. 76, a. 1.

${ }^{34}$ Aquinas, Compendium of Theology 18; Summa contra gentiles 2, chap. 46 and 86; 4, chap. 11; and Summa theologiae 1, qq. 76, a. 1 and 78, a. 1; 2-2, q. 179, a. 1. For Aquinas, humans are the only corporeal creatures capable of transcending the conditions of matter (Summa theologiae 1, q. 76, a. 1) because the human intellectual power is independent of matter (Summa contra gentiles 2, chap. 86) as it elevates the human soul beyond what is corruptible (Compendium of Theology 84). Because the human creature is endowed with intellectual capability, the human images and has the greatest likeness to God, he taught in Compendium of Theology 75, Summa theologiae 1, q. 93, a. 2, and Summa contra gentiles 2, chap. 46.

${ }^{35}$ Aquinas, On Truth 3, q. 24, a. 5, 11 and 27; God offers grace to humans to enable their cooperation with God's intention that they seek the temporal good in this life while aiming for eternal happiness. For an exploration of Aquinas's understanding of how the human can cooperate with God, see my "The Virtuous Cooperator: Modeling the Human in an Ecologically Endangered Age," Worldviews: Environment, Culture, Religion 7 (2003) 171-95. 
means through which human life can be sustained, and (2) as instruments or means through which knowledge of God can be obtained. ${ }^{36}$

Humans are expected to exercise their rational and volitional abilities when using other creatures, he insisted, since these abilities are intended by God to aid them in acquiring their temporal needs. ${ }^{37}$ The necessities of life are things that humans require to support their bodies, such as food, clothing, transportation ${ }^{38}$ and those things without which they cannot carry on their lives in appropriate ways as they seek eternal happiness with God. ${ }^{39}$ While the latter may appear initially to open to the possibilities of excessive use by some, Aquinas explicitly proscribed the exorbitant use of God's other creatures, describing it as inordinate and wasteful, ${ }^{40}$ immoderate, ${ }^{41}$ disordered, and vicious. ${ }^{42} \mathrm{He}$ judged the excessive use of other entities as sinful in the scheme of the human quest for eternity with God. ${ }^{43}$

Aquinas's teachings that humans can use other creatures to know God reflect his sacramental view of the physical world as a means through which God's goodness, wisdom, power, and other attributes can be contemplated. ${ }^{44}$ The physical world can lead humans to God, he contended, re-

${ }^{36}$ Aquinas, Summa contra gentiles 3, chap. 78 .

${ }^{37}$ Aquinas stressed repeatedly that humans should restrict their actions on other creatures to acquiring the necessities of life and knowing God as they seek their eternal goal; see, for example, Summa theologiae, Supp. q. 91, a. 1; 1-2, q. 4, a. 6-7; and q. 114, a. 10; 2-2, q. 76, a. 2; q. 83, a. 6; and q. 118 , a. 1 ; Summa contra gentiles 3 , chap. 22; and Compendium of Theology 173. Aquinas considered the human use of other creatures for the necessities of life and knowing God as an exercise of natural dominion; see, for example, Summa theologiae 2-2, q. 66, a. 1-2, Compendium of Theology 74, 127, and 148, and Summa contra gentiles 3, chaps. 78 and 111-112. In Summa theologiae 2-2, q. 66, a. 1, he insisted that God retains absolute dominion over both users and used.

${ }^{38}$ Aquinas, Summa theologiae 2-2, q. 141, a. 6; see also Supp. q. 91, a. 1; 2-2, q. 64 , a. 1 ; and q. 83, a. 6. Also see his Summa contra gentiles 3, chap. 22, 121, 129 and 131. Resounding throughout his works is the prescription that humans are intended to use only what is needed to sustain human life and not what is desired beyond the necessities of life.

${ }^{39}$ Aquinas, Summa theologiae 1-2, q. 4, a. 7; see also 2-2, q. 83, a. 6; q. 118, a. 1; and q. 141 , a. 6.

${ }^{40}$ Aquinas, Summa theologiae 2-2, q. 83, a. 6.

${ }^{41}$ Aquinas, Summa theologiae 2-2, q. 169, a. 1. For Aquinas's understanding of the "appropriate" use of things by humans, see Summa contra gentiles 3, chap. 129, where he teaches that some uses for the necessities of life are naturally fitting, whereas immoderate uses are naturally unfitting in the scheme of the integrity of the universe and, ultimately, in the human quest for eternal happiness with God.

${ }^{42}$ Aquinas, Summa contra gentiles 4, chap. 83.

${ }^{43}$ Aquinas, Summa theologiae 2-2, q. 118, a. 1; also see 2-2, q. 83, a. 6. See further Summa contra gentiles 4, chap. 83.

${ }^{44}$ Aquinas, Summa contra gentiles 2, chap. 2; also see 3, chap. 47, and 4, chap. 1. Summa theologiae 1, q. 65, a. 1, and 2-2, q. 180, a. 4 demonstrate his optimistic belief 
ferring occasionally to Romans $1: 20$ and Wisdom 13 , especially if they start from their faith perspective that the world is God's creation and approach it as a means of knowing about and loving God. ${ }^{45}$ Through their ability to make and execute informed decisions, an ability that distinguishes humans from other material creatures, humans should know that their eternal end is God and should act rightly to achieve that end. ${ }^{46}$

The great medieval theologian extended his understanding of the instrumental use of creatures by humans and by God. Humans also use other humans, he taught, and God uses all creatures for divine purposes. Other humans are the most important creatures a human uses, since they need one another to secure the necessities of life ${ }^{47}$ Moreover, all creatures are like God's instruments created to serve God's purposes, ${ }^{48}$ since whoever makes something for an end-a purpose-may use it to achieve that purpose. $^{49}$

Clearly, the instrumental value of all creatures looms large in patristic and medieval theological reflections. However, use by humans is limited to using other creatures to sustain human life, not to satisfy superfluous desires, and to knowing more about God.

\section{The Greater Goodness of the Totality of Creation}

Though patristic and medieval theologians valued each type of creature intrinsically in ways unique to their natures and instrumentally as means of sustaining themselves in the hierarchy of beings, they valued the entirety of the physical world most highly. They particularly valued the orderly functioning of the universe. According to their teachings, God wisely created the universe, generously endowed it with the capability of maintaining itself internally, and sustains it in existence. ${ }^{50}$

that humans have been gifted by God with the capacity to rise gradually from the world to limited knowledge of God. Aquinas expressed his sacramental view of the world in ways less emotive than found in works by Augustine, Hugh of St. Victor, Bonaventure, and Francis of Assisi. The sacramental quality of the world was explored frequently in patristic and medieval theological discourse as I demonstrate in "Acting Reverently in God's Sacramental World," in Ethical Dilemmas in the New Millennium II, ed. Francis A. Eigo (Villanova, Penn.: Villanova University, 2001) 37-90.

${ }^{45}$ Aquinas, Summa theologiae 1, q. 65, a. 1; see further 2-2, q. 180, a. 4, and Supp. q. 91 , a. 1.

${ }^{46}$ See, for example, Aquinas, Summa contra gentiles 1, chap. 92.

${ }^{47}$ Aquinas, Summa contra gentiles 3 , chap. 128 . Also see Summa theologiae 1 , q. 96 , a. 4 ; 2-2, q. 47 , a. 10.

${ }^{48}$ Ibid. 3, chap. 100.

49 Ibid. 3, chap. 64.

50 Tarsicius Van Bavel, O.S.A., rightly points to patristic theologians' ascription to the internal sustainability of the cosmos that God created and sustains in exis- 
Some theologians affirmed the superlative goodness of the physical world when reflecting on Genesis 1:31. For example, Augustine wrote that the ensemble of all entities constitute a "wonderful order and beauty." 51 There is a "tranquility of order" in the arrangement of "equal and unequal entities in their proper positions," and this arrangement brings about "the peace of the universe." 52 Indeed, "God has made all things very good," he exclaimed. ${ }^{53}$

Aquinas expounded systematically on the goodness of the universe that is brought about by the orderly functioning of its constituents in relation to one another. From his understanding that each type of creature has value, he described glowingly the unity brought about by their orderly interactivity as the greatest created good, ${ }^{54}$ the highest perfection of the created world, ${ }^{55}$ and its most beautiful attribute. ${ }^{56}$ The order of things to one another is the nearest thing to God's goodness, he insisted, because every particular good is ordered to the good of the whole. ${ }^{57}$ It is not contradictory for some things to exist for the sake of others and also for the sake of the perfection of the universe, he taught, since some are needed by others to maintain the internal integrity of the universe while all things are needed to contribute to its perfection. ${ }^{58}$ When all parts function in relation to one another in innately appropriate ways as intended by God, the universe is indeed perfect, it reflects God's goodness, and it manifests God's glory. ${ }^{59}$

tence ("The Creator and the Integrity of Creation in the Fathers of the Church, Especially in Saint Augustine," Augustinian Studies 21 [1990] 1-33). See also Howard J. VanTill, "Basil, Augustine, and the Doctrine of Creation's Functional Integrity," Science and Christian Belief 8 (1996) 21-38.

${ }^{51}$ Augustine, Enchiridion 10.

${ }_{52}$ Augustine, City of God 19, chap. 13.

${ }^{53}$ Augustine, Confessions 7, chap. 12.18. Also see City of God 11, chap. 22, for his theocentric theory about the need for "inequality" among creatures in the universe.

${ }^{54}$ Aquinas, Summa contra gentiles 2, chap. 39.7; see further 2, chap. 44 and 45; 3, chap. 69 and 144. Also see Summa theologiae 1, q. 15, a. 2 and q. 22, a. 1-2.

${ }_{55}^{55}$ Aquinas, Summa contra gentiles 2, chap. 45; see further chap. 44.

${ }^{56}$ Aquinas, Summa contra gentiles 3, chap. 71 . The universe cannot be any better than it is, he wrote in Summa heologiae 1, q. 25, a. 6, ad 3, because of the most beautiful order given to things by God. As John $\mathrm{H}$. Wright concludes from Aquinas's works in The Order of the Universe in the Theology of St. Thomas Aquinas (Rome: Gregorian University, 1957) 87; the universe is "God's masterpiece" with its excellence found in the ordered harmony of its parts.

${ }^{57}$ Aquinas, Summa contra gentiles 3, chap. 64 and 112. See also Summa theologiae 1, q. 47, a. 2. The integrity of all created beings is described in Summa contra gentiles 2, chap. 45 as the ultimate and noblest perfection in things which in turn are ordered to the ultimate uncreated good who is God.

${ }^{58}$ Aquinas, Summa contra gentiles 3, chap. 112.

${ }^{59}$ Aquinas, Summa theologiae 1, q. 65, a. 2. The interactive order of all things created by God is the greatest perfection and the most beautiful attribute of cre- 
While the intrinsic value of the orderly universe appears conclusive in the reflections of these three theologians, Aquinas explicitly addressed the instrumental use of the orderly universe by God. God uses the universe as its principal cause to produce its principal effect, ${ }^{60}$ which is a unity of diverse beings that function internally according to natural law established by God. ${ }^{61} \mathrm{~A}$ universe that functions as intended by God most superbly manifests God's goodness. ${ }^{62}$ Thus, the order of instrumentality begins with God and extends hierarchically downward to natural entities. While all types are intrinsically valuable as essential components of the universe, they are also instrumentally valuable to one another for their sustenance, and, as a totality, they are instrumentally valuable to God to achieve God's purposes. $^{63}$

\section{The Common Good}

Closely aligned with the greater goodness of the totality of creation is Aquinas's teaching that God created living and nonliving entities in an orderly relationship to one another to achieve their internal common

ation because it reflects the goodness and wisdom of God, Aquinas wrote in Compendium of Theology 102. Also see Summa contra gentiles 2, chap. 42; and Summa theologiae 1, q. 2, a. 3; q. 4, a. 2; and q. 13, a. 2 .

${ }^{60} \mathrm{St}$. Thomas Aquinas, On the Power of God (Qucestiones disputatce de potentia Dei), trans. English Dominican Fathers (London: Burns, Oates \& Washbourne, 1932) 3, q. 7 (hereafter cited as On the Power of God). James A. Weisheipl underscores this point in Friar Thomas D'Aquino: His Life, Thought, and Work (Garden City: Doubleday, 1974) 205.

${ }^{61}$ Aquinas, Summa theologiae 1-2, q. 93, a. 5. For Aquinas, natural law is the result of God's imposition of eternal law upon the universe at its creation to govern all things internally to their ends and ultimately to God; see, for example, Summa theologiae 1-2, q. 91, a. 1, and q. 93, a.1; also On Truth 1, q. 5, a. 1.6.

${ }^{62}$ Aquinas, Summa theologiae 1, q. 65, a. 2, and Compendium of Theology 102. See also Summa contra gentiles 2 , chap. $39,44-46$, and $68 ; 3$ chap. $64,69,71$ and 144 ; Summa theologiae 1, q. 15, a. 2; 22, a. 1-2; 25, q. 6 ad 3; and q. 47, a. 2.

${ }^{63}$ Oliva Blanchette observed in Aquinas's works an order of instrumentality among corporeal things. However, the order of instrumentality goes beyond human-corporeal parameters to encompasses the totality of existence with God as the ultimate mover of an instrumental order (The Perfection of the Universe according to Aquinas: A Teleological Cosmology [University Park: Pennsylvania State University, 1991] at 256). This more comprehensive instrumental order should be considered by contemporary critics who are troubled by Aquinas's view that other corporeal creatures are instruments for the human. For example, see H. Paul Santmire, The Travail of Nature: the Ambiguous Ecological Promise of Christian Theology (Philadelphia: Fortress, 1985) 90-91; also William C. French, "Catholicism and the Common Good of the Biosphere," in An Ecology of the Spirit: Religious Reflection and Environmental Consciousness, ed. Michael H. Barnes (Lanham, Md.: University Press of America, 1994) 177-94, at 193. 
good-the well-functioning of the universe ${ }^{64}$ Paralleling his treatment of the common good of the universe with the common good of citizens that constitute a particular society, he identified the common good as a basic principle in the way God governs the universe and in the way a king rules a kingdom. Both seek the good of many over the good of one. ${ }^{65}$

To achieve the common good, Aquinas continued, God instilled in each type of creature a natural inclination toward the good of the whole ${ }^{66}$ with each inclined intellectually, sensitively, or naturally to their mutual good. ${ }^{67}$ Stones and other entities without knowledge and sensation fall into the natural inclination category. ${ }^{68}$ Each type of creature is more strongly inclined to the common good than to itself, as demonstrated by its function within the universe. ${ }^{69}$ Sometimes creatures suffer damages to themselves for the sake of the common good. ${ }^{70}$ At the root of this appetite for the common good is the natural inclination each creature has for God who is the absolute common good of all creatures. ${ }^{71}$

While all parts are inclined toward the common good of the whole, Aquinas explained, entities that have a higher grade of goodness have a greater appetite for the common good, and they are inclined to seek to do good for others far removed from themselves. ${ }^{72}$ The human aptitude for the whole requires that a person will a particular good to the common good; if the person does not, that act of the will is not right. ${ }^{73}$

Human willing is supposed to be aimed toward the common good and

${ }^{64}$ Aquinas, Summa theologiae 1-2, q. 19, a. 10. The common good of the universe is its integrity which results from the order and composition of all its parts, Aquinas taught, for example, in Summa contra gentiles 3, chap. 94, On the Power of God 1, q. 6, a. 1, and Summa theologiae 1, q. 115, a. 3. Each part has an essential role to play in the whole; while some are better than others in their ways of being and acting due to their innate capabilities, all creatures are requisite for the functioning of the whole-contingent and noncontingent, corporeal and incorporeal, corruptible and incorruptible. See his discussion in Summa contra gentiles 1, chap. 85; On the Power of God 1, q. 6, a. 1; and Summa theologiae 1, q. 103, a. 7.

${ }^{65}$ Aquinas, On Truth 1, q. 5, a. 3.

${ }^{66}$ For example, see Aquinas, Summa theologiae 1-2, q. 109, a. 3, and 2-2, q. 26 , a. 3.

${ }^{67}$ Aquinas, Summa theologiae 2-2, q. 26, a. 3.

${ }^{68}$ Ibid. Also see Summa theologiae 1-2, q. 26, a. 1.

${ }^{69}$ Aquinas, Summa theologiae 1, q. 60, a. 5; see further 2-2, q. 26, a. 3, ad 2.

${ }^{70}$ Aquinas, Summa theologiae 2-2, q. 26, a. 3. He pointed specifically to citizens who suffer losses to their own property and themselves personally for the sake of their community's common good.

${ }^{71}$ Aquinas, Summa theologiae 1, q. 60, a. 5, ad 3-5; see further 2-2, q. 26, a. 3.

${ }^{72}$ Aquinas, Summa contra gentiles 3, chap. 24.8. Also see Summa theologiae 1, q. 57 , a. 2.

${ }^{73}$ Aquinas, Summa theologiae 1-2, q. 19, a. 10. His understanding of what is right is based ultimately on an action's being directed ultimately toward God. 
ultimately toward the individual's lasting relationship with God. Because humans often act incorrectly, God cares providentially for individual humans by offering them grace to help them exercise their wills appropriately ${ }^{74}$ God's grace both operates on and cooperates with humans toward their ultimate goal ${ }^{75}$ without interfering in the human exercise of freely making and carrying out decisions. ${ }^{76}$ God's grace operates lovingly on the human spirit so the individual thinks about and acts in ways that are conducive to achieving eternal life. ${ }^{77}$ God's grace cooperates with the human by actively sustaining the innate human capacity to make informed decisions and to choose to act accordingly. God's grace also operates on and cooperates with humans to develop moral virtues that will aid them in exercising their wills appropriately to achieve the common good in this life because they are motivated to achieve eternal life with God. $^{78}$

All entities that constitute the universe benefit from being moved toward the common good of the whole, Aquinas taught. ${ }^{79}$ Using a parallel example of the leader of an army, he maintained that the ordering of all parts to the good of the whole is what a leader of an army does when intending its

${ }^{74}$ Aquinas, Summa theologiae 1, q. 22, a. 2. Also see Summa contra gentiles 3, chap. 112-13 and On Truth 1, q. 5, a. 6-7. According to Aquinas, God's special care is needed for individual humans who have the capacity to think about how to act and to choose to act, capacities that humans often misuse. This special divine care for individual humans contrasts with God's general care for other species through natural laws embedded in the physical world because other-than-humans do not have intellectual capabilities or free will with which to deviate from God's intentions. God's care for individual humans and other species should be considered in relation to Aquinas's teaching in Summa contra gentiles 3, chap. 64, that among God's creation God cares most for the order of all things that constitute the universe.

${ }^{75}$ Aquinas, On Truth 3, q. 24, a. 11; see further q. 27, a. 5.

${ }^{76}$ This follows Aquinas's rationale that God governs all things to their end through God's eternal law, which God imposed on the universe in the form of natural law; see, for example, Summa theologiae 1-2, q. 91, a. 1, and q. 93, a. 1-5; and On Truth 1, q. 5, a.1. On his thinking about rational creatures who are ruled by eternal law and are rulers of themselves to whom God gives grace to seek their ultimate end, see Summa theologiae 1-2, q. 109, a. 1, and Summa contra gentiles 3, chap. 1 .

${ }_{77}$ Aquinas, Summa theologiae 1-2, q. 110, a. 1.

${ }^{78}$ See, for example, Aquinas, Summa theologiae 1, q. 111, a. 2, and On Truth 3, q. 27, a. 5. As Jacques Maritain explained in The Person and the Common Good, trans. John J. Fitzgerald (New York: Charles Scribner's, 1947) 7-10, when commenting on Summa theologiae 2-2, q. 3, a. 2, ad 2, before humans are "related to the immanent common good of the universe, they are related to an infinitely greater good-the separated common Good, the divine transcendent Whole."

${ }^{79}$ Aquinas, Summa theologiae 1, q. 11, a. 3; see further 1-2, q. 19, a. 10, on how the common good benefits all constituents of the universe. Also see Summa contra gentiles 1 , chap. $70 ; 2$, chap. 41 ; and 3, chap. 69 . 
mutual good. ${ }^{80}$ All members of the army benefit from the ordering of parts to one another that enables them to function appropriately so the good of the whole can be attained. ${ }^{81}$

Aquinas maintained that God intends all entities to cooperate for the good of the whole. In the operations of unintelligible beings, there is almost always harmony and usefulness in things because they are directed toward their ends by God. ${ }^{82}$ God also intends harmony and cooperation to prevail among all diverse constituents of the universe, including creatures gifted with the ability to think and to will the common good. ${ }^{83}$ As Joseph Legrand observed from Aquinas's teachings, no part of creation or type of creature is excluded from God's intention that all cooperate, combine, or harmonize within the order of the universe established by God to achieve the good that is common to all. ${ }^{84}$

When Aquinas contended that creatures cooperate in securing the common good, he was not only thinking about creatures cooperating among themselves within the hierarchical scale of beings that assures their internal sustainability. He also thought about the intercooperation of creatures as ways of cooperating with God. He insisted that higher creatures on the scale of beings are meant to cooperate with God in acquiring the good of the whole universe. A higher creature receives more abundant goodness from God as demonstrated by the creature's nature and way of acting. Unless the higher creature cooperates in procuring the good of lower creatures, the abundance of goodness given to the higher creature would be confined to one individual or few. ${ }^{85}$ The good of many is better than the good of an individual, he continued, and the good of the universe as a whole is best because it is more representative of the divine goodness.

Furthermore, Aquinas taught that goodness becomes common to many by the fact that the more richly endowed creature cooperates in procuring the good of many. ${ }^{86}$ Higher creatures are expected to cooperate in seeking the good of others, and it is with this expectation that God rules lower creatures through higher creatures.

Creatures cooperate with one another for the good of the whole, Aquinas reasoned, because they are related to God as their Creator. God ordered them to one another with the intention that they achieve their internal common good as an integral whole and thereby manifest God's

${ }^{80}$ Aquinas, Summa theologiae 1-2, q. 9, a. 1.

${ }^{81}$ Aquinas, On the Power of God 2, q. 4, a. 2, ad 29.

${ }^{82}$ Aquinas, On Truth 1, q. 5, a. 2

${ }^{83}$ Aquinas, Summa theologiae 1, q. 11, a. 3.

${ }^{84}$ Joseph Legrand, L'univers et l'homme dans la philosophie de Saint Thomas, 2 vols. (Brussels: Édition Universelle, 1946) 1:40.1

${ }^{85}$ Aquinas, Compendium of Theology 124.

${ }^{86}$ Ibid. 
goodness. In one of his most succinct treatments of this subject, Aquinas explained that the entire universe of interconnected parts achieves its purpose through the functioning of all parts in relation to one another in ways that are appropriate to the innate characteristics of each part. ${ }^{87}$ Functioning in these relational ways as an entirety of interconnected parts best manifests God's goodness and gives glory to God ${ }^{88}$ Thus, the created common good is the good of the whole order of beings functioning in appropriate, relational ways to sustain themselves as intended by God toward whom they aim as the uncreated common good of the entire universe.

William French contends astutely that Aquinas's notion of the common good provides a "cosmological-ecological principle" for his ethical system. ${ }^{89}$ From the perspective of ecological degradation today, the good sought in common would be the good of ecological systems of which humans are integral actors relying on other interacting biota and abiota for their health and well-being. This ethical framework of the common good for addressing environmental issues also appeals to Merle Longwood who recognizes the need for remaining cognizant of human existence in the "complex and subtly balanced system" of "the web of life" in which "all the parts function to maintain the quality of the integrated whole." 90

\section{God's Valuation}

Christian theologians have taught that God values the physical world with its many diverse constituents. Augustine counted the number of times

${ }^{87}$ Aquinas, Summa theologiae 1, q. 65, a. 2.

88 Ibid.

${ }^{89}$ French, "Catholicism and the Common Good of the Biosphere" 192. While French sees this organizing principle as a promising response to our contemporary ecological morass, he finds it often "overwhelmed" by another organizing principle which he describes as "the absolute superiority of rational human life over all lesser creatures," a premise for which he sees little room in theological ethics today. However, he does not factor into his evaluation the severe restrictions Aquinas places on how human beings function in relation to other creatures because of their mutual relationship to God. See also Robert P. George, "Natural Law, the Common Good, and American Politics," in The Battle for the Catholic Mind : Catholic Faith and Catholic Intellect in the Work of the Fellowship of Catholic Scholars, 1978-95, ed. intro. William E. May and Kenneth D. Whitehead (South Bend: St. Augustine, 2001) 308-21; and Brian J. Benestad, "How the Catholic Church Serves the Common Good," in ibid. 443-61.

${ }^{90}$ Merle Longwood, "The Common Good: An Ethical Framework for Evaluating Environmental Issues," Theological Studies 34 (1973) 468-80, at 479. I concur with Longwood's perceptive conclusion: "Our conception of the common good must obviously include the whole biotic community, since the quality and health of human life is integrally tied to the quality and health of the lives of all the other members of the biosphere. There is, after all, only one ecology, not a human ecology on the one hand and a subhuman ecology on the other" (479-80). 
in Genesis 1 that God is depicted as having created a being, observed it, and proclaimed it good. ${ }^{91}$ That God evaluates a creature and finds it good was significant from his faith perspective. ${ }^{92}$ God is the ultimate authority for valuations.

In a celebrated homily on Genesis 1 , Chrysostom stressed the authority of God's valuation. He warned his flock against the "arrogant folly" of failing to honor God's valuing of the physical world. He first told them to "shun ... like a lunatic" anyone who did not acquiesce to God's judgment about the world's goodness, and subsequently instructed them to inform the ignorant about God's valuation in order to "check" the ignorant person's "unruly tongue." ${ }^{93}$ God created everything by his loving and thoughtful kindness, according to Chrysostom. Nothing was created idly by God nor is any creature without purpose. ${ }^{94}$

Aquinas also ascribed ultimate authority to God's valuation of the physical world. Within his emanation-return schema of God's creating and governing the orderly universe, he found compatibility between the account in Genesis 1 of God's superlative evaluation of the entirety of creation and Aristotle's reasoning about the order of the universe as the greatest created good. ${ }^{95}$

Furthermore, Aquinas insisted that God cares most for the order of the universe. He reasoned that the nearest thing to God's goodness among created things is the good of the order of the universe, since every particular good is ordered to an end, just as the less perfect is ordered to the more perfect culminating in the human, and each part, including the human, is for the sake of the whole. ${ }^{96}$

Even more profoundly, Aquinas taught that God loves the orderly universe with the highest kind of love-ex caritate. ${ }^{97}$ While God loves all creatures ex amore, the love of desire that they exist ${ }^{98}$ and are useful to rational creatures in their temporal lives, ${ }^{99}$ and God loves ex amore and $e x$ caritate rational creatures more than another kind of creature or several creatures because rational creatures can participate in God's goodness as their eternal end, ${ }^{100}$ God loves the universe ex caritate more than God loves

91 Augustine, Confessions 13, chap. 29.44.

92 Augustine, Confessions 13, chap. 31.46: "No less rightly is it said to those who see in the Spirit of God, 'It is not you who see,' so that whatsoever in the Spirit of God they see to be good, it is not they but God who sees that it is good."

${ }_{93}$ Chrysostom, On Genesis, Homily 10.13, 137.

94 Ibid.

${ }_{95}$ Aquinas, Summa contra gentiles 3, chap. 64.

${ }^{96}$ Ibid.

${ }^{98}$ Aquinas, Summa theologiae 1, q. 20, a. 3.

99 Aquinas, Summa theologiae 1, q. 20, a. 2, ad 3.

${ }^{100}$ Aquinas, Summa contra gentiles 3, chap. 90. Also see Summa theologiae 1-2, q. 110 , a. 1 . 
rational creatures or any other or several kinds of creatures. ${ }^{101}$ This is because the order of creatures to one another to achieve their common good best manifests God's goodness as perfectly as creatures can. ${ }^{102}$

From these teachings emerges an understanding of God's intrinsicinstrumental valuing of the entire universe of diverse living and nonliving entities. God values the entire universe most as a functioning whole of intrinsically valuable beings that achieve their purposes for existing by acting or being acted upon according to their natures. God also values all types of beings as instruments of other beings progressively up the hierarchical chain by which the universe maintains itself. ${ }^{103}$ Furthermore, the universe is like God's instrument for achieving the divine purposes for it, ${ }^{104}$ thereby serving eminently as the best possible manifestation of God's goodness. ${ }^{105}$

\section{Human Valuation}

Augustine connected human valuing of the physical world with human limitations and self-centered tendencies. Humans are gifted with intellectual abilities, he explained, but our entrenchment in a part of the universe and our condition as mortal beings prevents us from comprehending the universe in its entirety. Only God has this all-encompassing intellectual capacity. Nevertheless, humans should overcome their narrow-mindedness

${ }^{101}$ Aquinas, On Charity 7 ad 5; Aquinas insisted that God loves the orderly universe maxime ex caritate.

${ }_{102}$ Aquinas, Summa theologiae 1, q. 65, a. 2, and Compendium of Theology 102.

${ }^{103}$ Aquinas, Summa contra gentiles 3, chap. 100; following Aristotle's commentary on De anima 2.6, Aquinas noted that animals use plants and inanimate things while plants use inanimate things by taking nourishment and support from them. In On the Power of God 1, q. 5, a. 9, he taught that it is not contrary to the nature of any created thing when it is moved in any way by God, since all things were created the way they are in order to serve God. Thus, for Aquinas, the entirety of creation is like an instrument that produces its principal effect when being used by its principal cause. Weisheipl confirms Aquinas's instrumental view in Friar Thomas D'Aquino 206.

${ }^{104}$ Aquinas, Summa contra gentiles 3, chap. 100, and On the Power of God 1, q. 3, a. 7 ad 3, and q. 5, a. 9. See also Weisheipl, Friar Thomas D'Aquino 206. In Summa contra gentiles 3 , chap. 100, Aquinas explained that instruments are made for the purpose of subserving the action of the principal agent while being moved by that agent, so it is not contrary to the nature of any created thing when it is moved in any way by God since all things were made the way they are in order to serve God. In On the Power of God 1. q. 3, a. 7, ad 3, he taught that the entirety of creation is like an instrument that produces its principal effect by being used by its principal cause.

${ }^{105}$ For example, see Aquinas, Summa theologiae 1, q. 65, a. 2; q. 15, a. 2; q. 22 , a. 1-2; and q. 25, a. 6 ad 3; Summa contra gentiles 2, chap. 39, 44, and 68; and Compendium of Theology 102. 
and self-centeredness that is manifested by judging negatively some natural beings and forces that cause them personal discomforts. Humans should consider the natures of things in themselves without regard to their convenience or inconvenience, their pleasantness or unpleasantness, their comfort or discomfort. Humans should praise God for all aspects of the physical world and never "in the rashness of human folly" allow themselves to find fault in any way with the work of the "great Artificer." Humans must have confidence in God's overall design, God's continuing care, and God's purpose for all things that comprise the beautiful universe. ${ }^{106}$

In addition to addressing the intrinsic value of the physical world, Augustine focused on the human use of other creatures. God created all things in supreme wisdom and ordered them in perfect justice to one another. To humans God has given good things suitable to this life, including light to see, air to breathe, water to drink, and food to eat. Every human who uses these goods correctly "shall receive goods greater in degree and superior in kind, namely the peace of immortality" within which God can be enjoyed eternally. The person who uses these goods incorrectly "shall lose them and shall not receive the blessings of eternal life."107

Chrysostom characterized Earth as "mother and nurse" created by God to nourish humans. ${ }^{108}$ They are destined by God to enjoy Earth as their "homeland" for which they should be grateful to God. ${ }^{109}$

Aquinas also reflected on human valuation of the physical world from intrinsic and instrumental perspectives. As John F. Kavanaugh notes, when describing the human as a creature with the cognitive capacity to recognize the goodness of the physical world and the volitional capacity to choose to value it, Aquinas presented the human as an intrinsic valuer. ${ }^{110}$ His teaching about the human capacity to discover the rational plan by which God directed one creature to the other ${ }^{111}$ also opens to recognizing humans as instrumental valuers. Upon discovering the instrumental relationships of entities to one another that brings about their sustainability as intended by God, humans should value them and their interactions.

That humans should value the physical world with its diverse constituents is also supported by Aquinas's teaching that God has given humans a

106 Augustine, City of God 12, chap. 4.

${ }_{107}$ Ibid. 19, chap. 13.

${ }^{108}$ Chrysostom, On Genesis, Homily 9.3. He also describes earth as the human "tomb" to which the human body would return.

${ }^{109}$ Ibid. 10.12 .

110 As Kavanaugh notes, the "intrinsic value" approach, "stresses that there are certain actions which, no matter what the external factors or the internal motives, are somehow profoundly evil in themselves, independent of their usefulness or our intentions" ("Intrinsic Value, Persons and Stewardship" 71).

${ }^{111}$ Aquinas, Summa contra gentiles 3, chap. 78 . 
"natural dominion" over God's creation while God maintains "absolute dominion." $" 112$ The natural dominion exercised by humans is based on the ability to know and to will good ends, and humans are always subservient to God's dominion when exercising their dominion which, contra William French, is never "absolute." 113 Thus, human dominion is aimed at cooperating with God in carrying out God's plan for the universe and not hindering it in any way. ${ }^{114}$

Another dimension of valuing the physical world intrinsically and instrumentally is Aquinas's teaching that humans can also love the entire universe of diverse beings with the highest kind of love-maxime et caritate. ${ }^{115}$ He specified two ways: (1) as good entities that should be conserved for God's honor and glory; ${ }^{116}$ and (2) as goods needed by other humans as they seek eternal happiness with God. ${ }^{117}$ The intrinsic and instrumental valuations surface explicitly from these two ways of loving the universe of many varied beings ex caritate to the maximum possible extent.

Finally, Aquinas's praise for the orderly interaction of natural beings that maintains the integrity of the physical world provides an exemplar for also valuing the integrity of the universe through which the temporal common good-its sustainability-is realized. His teaching that humans should seek the common good when willing a particular good ${ }^{118}$ provides an entry into thinking more expansively about valuing the functioning of the physical world. The sustainable functioning of ecosystems and the greater biosphere is indeed a good that humans have in common with other biota and abiota that comprise these systems. When humans will that common good, they are conforming their wills to God's valuation of the physical world. ${ }^{119}$

\section{ETHICAL IMPLICATIONS THROUGH A 21st-CENTURY LENS}

From these selected reflections on the goodness of creation emerge several significant implications for a system of ethics that can be responsive to ecological degradation. All species, the air, land, and waters are valuable intrinsically as components of Earth; they are also valuable instrumentally as needed by other components to sustain themselves within the web of life. Ecological systems are valuable intrinsically as a composite of intrin-

${ }^{112}$ Aquinas, Summa theologiae 1, q. 96, a. 1.

${ }^{113}$ French, "Catholicism and the Common Good of the Biosphere" 192.

114 Aquinas, Summa contra gentiles 3, chap. 78-79.

115 Aquinas, On Charity 7, ad 5.

${ }_{116}$ Aquinas, Summa theologiae 2-2, q. 25, a. 3 and 11.

${ }^{117}$ For example, see Aquinas, On Charity 3; and Summa theologiae 2-2, q. 23, a.

8 , and q. 47 , a. 1 , ad 1 .

${ }_{118}$ Aquinas, Summa theologiae 1-2, q. 19, a. 10.

119 Ibid. 
sically-instrumentally valuable biota and abiota functioning interdependently to sustain their shared existence; they are also valuable instrumentally for their contributions to the sustainability of the larger biosphere. The biosphere is valuable intrinsically as the composite of all systems with biotic and abiotic constituents along with adjoining marginal areas that altogether constitute Earth; the biosphere is also valuable instrumentally as a home used by humans, other species, and ecological systems. The entirety of the physical world with its many diverse constituents is valuable to God, their purposeful creator and sustainer in existence, who endowed humans with the intellectual capacity to discern the intrinsic and instrumental values of the physical world, to behold these values, and to demonstrate these valuations throughout their lives.

\section{Parallels with Secular Philosophical Issues}

Some of these implications for ethics parallel broadly the proposals proffered by both intrinsic and instrumental value theorists over the past 25 years. A particularly prominent parallel with patristic and medieval thinking is Rolston's position that value is a property of the physical world that preexists humans and is available for discovery by them. For Christian theologians, God bestows and upholds the physical world's value, God's valuing preexists humans, and faith-filled Christians who desire eternal happiness with God have a strong incentive both for using their intellectual capabilities to discover the value of individuals, species, the air, land, water, ecological systems, their marginal areas, the biosphere, and the entire universe and for demonstrating their valuations.

Another important parallel between the earlier theologians and some current environmental ethicists is the good of the whole as the basis for adjudicating conflicts between humans and other species. Callicott promotes this common good adjudication in principle through Aldo Leopold's "land ethic," Longwood through the Aristotelian concept of "the common good," and French and Kavanaugh through Aquinas's Christianization of Aristotle's understanding of the common good. Maintaining the sustainability of natural entities individually and collectively is their common good that is intended by God as explained in its fullest sense by Aquinas. Thus, all claims would have to be adjudicated on the basis of the extent to which the claim is essential to the sustainability of an entity according to its nature, its purpose within the ecological system, and the overall sustainability of that system.

While human claims for using individuals of other species, the air, the land, and waters would have to meet this common good criterion, human claims could advance beyond bodily existence to encompass spiritual needs. A primary spiritual need for present and future generations is the 
opportunity to experience God's presence and goodness through the physical world. Honoring spiritual claims places additional constraints on human use in order to assure that other humans now and into the future are not prevented from encountering God through the world. Among these constraints are avoiding actions that precipitate the extinction of a species, the loss of biodiversity in an ecological system, the pollution of air, waterways and land, the widening of the rupture in the ozone layer of Earth, and the littering of cosmic "space."

Requiring humans to constrain their use of other creatures to the necessities of life corresponds with the philosophy of "deep ecology" developed by Arne Naess, Bill Devall, and George Sessions. Deep ecologists recognize the legitimacy of human use of other species and abiota, though they insist it must be balanced by valuing them intrinsically in order to minimize the impact on the physical environment. ${ }^{120}$ As indicated previously, patristic and medieval theologians taught Christians to consume only what is needed to sustain their temporal lives while preparing for their eternal destinies with God. They also reflected on a belief that further constrains human use and that is without parallel in secular philosophy-God's presence is experienced in the world and God's attributes are known through the world. This sacramental character of Earth, its ecological systems, and their species requires valuing them both intrinsically and instrumentally. ${ }^{121}$

\section{Updating Patristic and Medieval Notions}

However promising patristic and medieval notions about the goodness of God's creation and its intrinsic-instrumental value appear to be, their reformulation is essential to reflect our contemporary understanding of the world so the system of ethics developed is as relevant and meaningful as possible. Augustine, Chrysostom, Aquinas, and their contemporaries viewed the world as geocentric, its diverse constituents as having been created with time as specific types ordered hierarchically in relation to one another to function as God intended with freedom allowed only for the human will, and each creature as having a purpose in God's plan. The goodness of creatures and the superlative goodness of the world in its totality were attributed directly to God's having created them as they were observed through the senses. Thus, their valuation was tied to the "fixed"

${ }^{120}$ Arne Naess, "The Deep Ecological Movement: Some Philosophical Aspects," Philosophical Inquiry 8 (1986) 10-31; Bill Devall and George Sessions, Deep Ecology: Living as If Nature Mattered (Salt Lake City: Gibbs Smith, 1985). Deep ecologists also insist that the human use of other species must be balanced with their intrinsic value so the impact on the environment is minimal.

${ }^{121}$ The term "sacramental" is used in the broadest sense to convey the understanding that God's presence and character can be experienced through the world. 
specificity of the wondrous world as seen through their patristic and medieval lenses.

Our current understanding of the world is vastly different. According to scientific findings and theories, the universe has been expanding from perhaps a finite singularity for approximately 13.8 billion years. Billions of galaxies have been discovered with billions of stars. The furnaces of stars produced carbon, nitrogen, and other elements essential for life to emerge on at least one planet that revolves around one middle-aged star. Relationships within the biological evolutionary process are dynamic, interdependent, and holistic. ${ }^{122}$ An interplay of physical laws and chance seems to be operative with an openness to a future that cannot be predicted with accuracy. Though humans have capacities not yet discovered elsewhere, we are products of this evolutionary process and radically related to and interconnected with everything living and nonliving in the universe, especially the constituents of Earth. Humans are also radically dependent upon other species, the air, the land, water, ecological systems, and the biosphere for our health and well-being.

In order to be meaningful, theological discourse must be realistic about the world as disclosed through scientific investigations and relevant to the ecologically endangered times in which we live. Discourse can be meaningful for monotheists by beginning to reflect from a position of faith in God, the purposeful creator who sustains the world and values its totality, and by proceeding to inform this basic faith with broad scientific findings. From a scientifically informed faith perspective, God's relation to the world can be reflected upon and norms for valuing its constituents can be discerned.

This "critical-creative" approach to rethinking notions in the Christian tradition and informing them with current scientific findings ${ }^{123}$ yields an understanding of God as willing the universe to exist, sustaining and empowering its dynamic self-organization over time and expanding space, calling forth the fullest expression of the universe, and valuing its unfolding complexity, the diversity of its emerging constituents, and their interacting relationships to one another for their common good. The physical world can be understood as God's valuable possession, a manifestation of God's

122 In Conservation Biology: The Theory and Practice of Nature Conservation, Preservation, and Management, ed. Peggy L. Fiedler and Subodh K. Jain (New York: Chapman and Hall, 1992), Steward Pickett, Tom Parker, and Peggy Fiedler point in to the shifting mosaic of the physical world which is in continuous flux; see their "The New paradigm in ecology: Implications for conservation biology above the species level." For the authors, "[h]uman-generated changes must be constrained because nature has functional, historical, and evolutionary limits."

${ }^{123}$ This approach is demonstrated in my "Appreciating the Beauty of Earth," Theological Studies 62 (2001) 23-52. 
extravagant goodness, and a readily available subject for discovery. Faithfilled humans can be understood as discoverers of the physical world's value, beholders of its value, and responders to that value $e^{124}$ out of a desire to share in God's valuation for the common good of constituents in the past, present, and future.

\section{Application to an Ecological System}

When applied to an ecological system, the effectiveness of this method can be demonstrated. Consider, for example, the Everglades, an immense fresh water marsh ${ }^{125}$ that covers 4000 square miles of the southern tip of Florida. Called Pa-hay-okee (grassy waters) by the natives because of the various species of sedges and grasses that grow in the marsh, ${ }^{126}$ the Everglades begins as an overflow from Lake Okeechobee in central Florida and flows southward and westward until it enters Florida Bay. This slowmoving mass of water houses a unique composite of ecosystems found nowhere else on Earth. ${ }^{127}$ Among them are mangrove swamps, cypress domes, pinelands, marl and coastal prairies, mahogany hammocks, and intertidal zones. Within these ecosystems are 600 animal species, 300 species of birds, 1000 varieties of plants, and 120 varieties of trees including the unique apple pond. ${ }^{128}$ Since the 1920 s, a vast network of ditches and dikes have been constructed in millions of acres of the Everglades to control floods, and millions more have been drained to create more dry land for agri-business and development projects. Only 48 percent of the original acreage of the Everglades remains, approximately $90-95$ percent of the

${ }^{124}$ Holmes Rolston III uses this model for humans as "beholders of value" in Duties to and Values in Nature (Philadelphia: Temple University) 112-17. See also Keekok Lee's affirming discussion in "The Source and Locus of Intrinsic Value: A Reexamination," Environmental Ethics 18 (1996) 297-309.

${ }^{125}$ A shallow wetland with few trees and standing water for most of the year.

${ }^{126}$ E.g., Sawgrass (Cladium jamaicense) which grows up to ten feet tall and house immense flocks of wading birds, fish, exotic plants, alligators, and numerous invertebrates, which is the dominant grass (actually a sedge) found in the freshwater marshes of the Everglades.

${ }^{127}$ Among the informative studies of the Everglades are Steven M. Davis and John C. Ogden, Everglades: The Ecosystem and Its Restoration (Delray Beach: St. Lucie, 1994); Thomas E. Lodge, The Everglades Handbook: Understanding the Ecosystem (Boca Raton: St. Lucie, 1998); Marjory Stoneman Douglas, The Everglades: River of Grass (Sarasota: Pineapple, 1988); Peter Lourie, Everglades: Buffalo Tiger and the River of Grass (New York: Boyds Mills, 1994); Diane Raines, Water Wars: Drought, Flood, Folly, and the Politics of Thirst (New York: Riverhead, 2002); David McCally, The Everglades: An Environmental History (Gainesville: University Press of Florida, 1999); and James P. McMullen, Cry of the Panther: Quest of a Species (Englewood: Pineapple, 1984).

${ }^{128}$ Lodge, The Everglades Handbook. 
wading bird population of the Everglades has been lost since the $1930 \mathrm{~s},{ }^{129}$ and 71 species of its natural wildlife are federally listed as endangered or threatened, including the American crocodile, the Florida panther, ${ }^{130}$ the Red-cockaded woodpecker, and the Cape Sable seaside sparrow, a songbird unique to the Everglades and widely considered to be an indicator of the overall health of its habitat. ${ }^{131}$ The quality of the water has been adversely affected by human activities, the most significant of which are rock mining and the phosphorus-tainted runoff from sugarcane plantations. An explosion of cattail growth and a proliferation of nonnative species have displaced native vegetation and destroyed wildlife habitat. To address the deterioration of the Everglades, the United States Congress authorized a multibillion-dollar restoration plan. Foundations, task forces, and environmental defense groups are closely monitoring and participating in this planning. ${ }^{132}$

The Christian tradition can be drawn upon to motivate believers to join others in addressing the dire condition of the Everglades. When thinking with Augustine, Chrysostom, and Aquinas about the goodness of creation, the waters, grasses, trees, invertebrates, ${ }^{133}$ plants,,${ }^{134}$ amphibians, ${ }^{135}$ fish,,${ }^{136}$ mammals, ${ }^{137}$ the bottoms of the marshes, and the land of the hardwood forests can be acknowledged as good and valuable both intrinsically and

129 This figure includes seven percent of the egrets, herons, and other wading birds that once inhabited the Everglades.

${ }^{130}$ Perhaps the most famous, elusive, and imperiled resident of the Everglades is the Florida panther, a big, tawny cat that is a subspecies of mountain lion; no more than 30 to 50 are believed to remain in the wild.

${ }^{131}$ Also the Green turtle, Atlantic Ridley turtle, Atlantic hawksbill turtle, Atlantic leatherback turtle, Cape Sable seaside sparrow, Everglades Snail Kite, wood stork, West Indian manatee, Key Largo wood rat, Key Largo cotton mouse, Schaus swallowtail butterfly, and Garber's Spurge.

${ }^{132}$ See, for example, the South Florida Ecosystem Restoration Task Force, http:// www.sfrestore.org/, the Everglades Foundation,http://www.saveoureverglades.org/ about/about.html, and the Natural Resources Defense Council, http:// www.savebiogems.org/everglades/.

${ }^{133}$ Invertebrates of the Everglades include spiders, scorpions, pond crayfish, a plethora of butterflies, dragon flies, grasshoppers, mantids and other insects, marine invertebrates of many types including many varieties of crabs, sea stars, conches, sponges, and snails.

${ }^{134}$ Approximately one hundred and forty exotic, invasive plant species have become established within the boundaries of Everglades National Park. With few or no natural predators in their new environment, invasive species flourish, replacing natives, and altering the landscape and functioning of the ecosystem.

${ }_{135}$ Cuban Tree Frog and Southern Leopard Frog.

${ }^{136}$ Cartilagenous fish include the Southern Stingray; Bony fish include the Atlantic Needlefish, French Angelfish, Lizardfish, Puffer, and Spotfin Mojarra.

${ }^{137}$ For example, the common racoon, Florida panther, and manatees. Manatee protection efforts were necessary in Florida because people sometimes behaved in 
instrumentally. They are valuable intrinsically as natural entities that have emerged in the Everglades over evolutionary time, having been and continuing to be shaped by the other constituents of the Everglades, and all contribute some essential aspect to the complex Everglades ecological system. These constituents are also instrumentally valuable as entities that interact with one another in their particular ecological systems for their sustenance. For example, the grebe eats the little fish that hide among the roots of the water plants that are stirred up by the ibis when digging its bill among the roots of the vegetation. The various smaller ecological systems ${ }^{138}$ are valuable intrinsically as functioning areas that contribute and take from the flowing waters of the Everglades, and they are also instrumentally valuable through their use by the Everglades as a whole. The sustainability of the Everglades outweighs the good of any one contributing ecological system or any one of the system's components, since all are parts of the macro Everglades system and essential to sustain its viability.

Thus, the religious motivation for intrinsic-instrumental valuing of other species, abiota, and ecological systems becomes evident when notions about the goodness of creation are informed by current scientific findings about the physical world. Identifying norms to guide human behavior remains a challenge.

\section{ETHICS OF INTRINSIC-INSTRUMENTAL VALUING}

A meaningful and potentially effective system of intrinsic-instrumental valuing surfaces when foundational notions about the goodness of other species, ecological systems, and the biosphere are reworked to reflect our current scientific view of the world. Five basic principles flow systematically for people who believe in God to follow:

(1) Value the evolutionary process out of which all physical entities, including humans, have emerged. ${ }^{139}$ Empowered by God into existence with the ability to develop itself, the physical world has unfolded through an interplay of basic laws of physics and chance into a vast diversity of galaxies

inappropriate ways-pursuing animals in boats, trying to hold or "ride" the animals, and even sadistically injuring or killing them.

${ }^{138}$ Mangrove swamps, cypress domes, pinelands, marl and coastal prairies, mahogany hammocks, and intertidal zones.

${ }^{139}$ In Life's Dominion: An Argument about Abortion, Euthanasia, and Individual Freedom (New York: Alfred A. Knopf, 1993) 76, Ronald Dworkin makes an astute observation when reflecting on the creativity of the evolutionary process and the parallel valuing of species by those who believe in God who can view the evolution of species as part of God's authorship of the physical world and by those who ascribe to a purely secular view of species as "achievements of adaptation" over long and complex periods of time. From both perspectives, to cause a species extinction is a "frustration" of "investments" that are "worthy of respect." 
with billions of stars, other cosmic phenomenon, and planets. At least one planet has a diversity of biological life, including reflective beings with the capacity to discover value and demonstrate their valuations. Having emerged from and with other entities through this cosmological-biological process, humans should value it by functioning constructively within it so the process can continue to produce more valuable entities. ${ }^{140}$ Humans can also value the process instrumentally as the conduit through which the necessities of life have emerged and facilitated the flourishing of species. Because there are functional, historical, and evolutionary limits to the physical world, humans will strive to know those limits and live within them. ${ }^{141}$ By cooperating with other species, abiota, ecological systems, and the biosphere, humans will be cooperating with God's gratuitous and loving empowerment of that creative process.

(2) Discover and value the innate goodness of the various species and other natural entities, their interests, and their needs to survive in the world. With Augustine, Chrysostom, and Aquinas, people who profess faith in God will discover the intrinsic value of each species, the air, land, and water, and they will demonstrate their valuation accordingly. In addition to homo sapiens, all other species will be valued in themselves as entities that have emerged with humans over time and space. Integral to discovering their value is the need to discern their interests in surviving and needs for surviving. Interference with these needs and interests will be avoided locally to globally. Species' habitats will be protected, and lists of threatened and endangered species will diminish. Efforts will be expended to curtail pollutants and persistent toxicants from the air, water, and land.

(3) Discover and value the instrumental relationship of innately good beings to one another. While intrinsically valuable, the instrumental value

${ }^{140}$ Holmes Rolston III explains: “There is a kind of 'promise' in nature not only in the sense of potential that is promising but in the reliability in the earthen set-up that is right for life. Perhaps the planetary set-up is an accident, but the ongoing after the set-up seems to be loaded with fertility .... It seems a shame now for humans to break that "promise." ("Disvalues in Nature," The Monist 75 (1992) 250-80). See further, John F. Haught, The Promise of Nature: Ecology and Cosmic Purpose (New York: Paulist, 1993). J. Baird Callicott explores the continuity of the human self and nature and insists that nature is intrinsically valuable if "the self is intrinsically valuable." He reasons further: "If it is rational for me to act in my own best interests, and I and nature are one, then it is rational for me to act in the best interests of nature" ("Intrinsic Value, Quantum Theory, and Environmental Ethics" 275).

${ }^{141}$ In "The New Paradigm in Ecology," Pickett, Parker and Fiedler point to the shifting mosaic of the physical world which is in continuous flux. "Humangenerated changes must be constrained because nature has functional, historical, and evolutionary limits. Nature has a range of ways to be, but there is a limit to those ways, and therefore, human changes must be within those limits." 
of species, air, land, and water to one another will also be discerned and valued by people who believe in God as the creator, sustainer, and ultimate valuer of the physical world. Land species use air, water, land, and other species to maintain themselves, marine species use water and select species of food to maintain themselves, and airborne species rely on water, land, and other species to sustain themselves. Humans use individuals of other species for food and other goods needed for their lives and well-being, though too many humans in economically developed nations use other biota, abiota, and whole ecological systems to try to satisfy their insatiable desires. Instead of thinking about other species, air, land, and water exclusively from the perspective of their usefulness to humans, faith-filled people will recognize and value the use that other species have for one another, the air, land, and water for their sustenance in the complex web of life.

(4) Discover and value the unique contribution that each species, air, land, and water makes to their shared ecological systems. Following Augustine, Chrysostom, Aquinas, and other eminent theologians, people who profess faith in God will discover and acknowledge the contributions that species and abiota make to their shared ecological systems. They will be valued as God's creatures that are valued by God for their contributions to the integrity of ecological systems. Actions that inhibit their contributions will be prevented. Proposed projects will be scrutinized to assure that each constituent can continue to contribute.

(5) Discover and value the functioning of ecological systems and the biosphere to achieve their common good-their sustainability-now and into the future. In addition to valuing the contributions that constituents make to their shared ecological systems, the overall functioning of these systems should be valued both intrinsically and instrumentally. The combination of the complex interactions of biota and abiota that create and recreate an ecological system ${ }^{142}$ should be discovered and sufficiently valued intrinsically by controlling human actions so they avoid disrupting a system's natural functioning and, thereby, deter it from achieving its common good. So, too, will people value the functioning of Earth's interactive constituents as the best manifestation of God's goodness, as Aquinas taught.

In light of the fact that humans rely upon the land, air, waters, and other species for human well-being and that humans function as integral but often degrading constituents of those systems, people who profess faith in God will instrumentally value the systems in which they live by taking from them only what is needed to sustain their lives in ways and doing so in ways that avoid endangering the system's sustainability. With Aldo Leopold,

${ }^{142}$ See David Lodge, "From the Balance to the Flux of Nature: The Power of Metaphor in Cross-Discipline Conversations," Worldviews: Environment, Culture, Religion 7 (2003) 1-4. 
faith-filled people will think about themselves as citizens of ecological systems rather than conquerors of them. ${ }^{143}$ Faith-filled people will be inspired by the shared thinking of Augustine, Aquinas, and other theologians about the sacramentality of creation so as to value the functional integrity of ecological systems and the biosphere as the best manifestation of God's goodness. They will also be inspired by theologians' thinking about the instrumental use of creation as human means through which they can learn more about God's attributes.

Following this principle, the sustainability of Earth will become the chief organizing principle around which moral decisions will be made. This principle is, as Longwood insists, the best framework for addressing the ongoing degradation of Earth. ${ }^{144}$ The principle of Earth's sustainability is also conducive to the "cosmological-ecological principle" that French identifies from Aquinas's works. ${ }^{145}$ And, it is the "fertile ground" that should satisfy Kavanaugh for assuring that valuing other-than-humans is not merely for human benefit. ${ }^{146}$ With Tanner, people who believe in God as the creator and sustainer of the world will "repudiate any such alternative between concerns for environmental well-being, on the one hand, and sensitivity to issues of human justice, on the other." ${ }^{147}$ All actions will be adjudicated on

${ }^{143}$ Aldo Leopold, Sand County Almanac: With Essays on Conservation from Round River (New York: Ballantine, 1949) 203-4.

${ }^{144}$ Longwood insists when dealing with environmental issues that "we have to be cognizant of the way in which we exist in the web of life, which is a complex and subtly balanced system in which all parts function to maintain the quality of the integrated whole, the concept of the common good seems particularly appropriate. Our conception of the common good must obviously include the whole biotic community, since the quality and health of human life is integrally tied to the quality and health of the lives of all the other members of the biosphere. There is, after all, only one ecology, not a human ecology on the one hand and a subhuman ecology on the other" ("The Common Good: An Ethical Framework for Evaluating Environmental Issues" 479-80).

${ }_{145}^{145}$ French, "Catholicism and the Common Good of the Biosphere" 192.

${ }^{146}$ Kavanaugh explains that Aquinas's "metaphysics and anthropology provide ground fertile enough for raising stewardship as an ethical issue" ("Intrinsic Value, Persons and Stewardship" 67). He offers "a contemporary account of Aquinas's 'intrinsic value' theory as a nominee for the foundation upon which the issue of stewardship can be based." This approach "recognizes an intrinsic goodness and value to every existing being, regardless of its role as a function of our happiness or motives. The 'intrinsic value' approach ... stresses that there are certain actions which, no matter what the external factors or the internal motives, are somehow profoundly evil in themselves, independent of their usefulness or our intentions."

${ }^{147}$ Katherine Tanner argues: "Putting human and non human beings together in this way within a single community of moral concern helps resolve certain issues for human decision making." She encourages people who believe in God as Creator "to explore ways in which human action might alter circumstances of competition and 
the basis of the shared common good of the constituents of ecological systems and the biosphere to sustain themselves. All conflicts would be settled on the basis of the extent to which the claim seeks the necessities that sustain the claimant's existence so the claimant can continue to contribute to the internal functioning of an ecological system and the greater biosphere. Needs will always take precedence over wants in moral decision-making. ${ }^{148} \mathrm{~A}$ vision of the future informed by the present will be essential to making prudent decisions at all levels of human society. ${ }^{149}$

\section{CONCLUSION}

The ethics of intrinsic-instrumental valuing based on reformulated patristic and medieval notions about the goodness of creation provides a meaningful, relevant, realistic, and potentially effective system of environmental ethics. It is readily available for application today by people who profess faith in God as the creator and sustainer of the world and who believe that humans are responsible to God for how they act in this world. From this religious faith perspective, difficult issues with which secular philosophers have been grappling can be addressed. Other-than-humans are valuable intrinsically as well as instrumentally as they struggle to sustain their shared existence with humans. The intrinsic value of other-thanhumans originates with God who empowers the evolutionary process out of which all entities emerge. Their intrinsic-instrumental value persists in this process, and their value is discoverable by humans who have the ability to discern and demonstrate their valuations. Finally, a system of ethics based on the common good-the sustainability of all constituents in their shared ecological systems and the greater biosphere-serves to adjudicate conflicts among valued beings.

Five initial principles flow from reworked notions about the goodness of the physical world. People who profess faith in God should value the

bring the earth closer to a vision of a truly universal, world-inclusive, equal justice" ("Creation, Environmental Crisis, and Ecological Justice," in Reconstructing Christian Theology, ed. Rebecca S. Chopp and Mark Lewis Taylor [Minneapolis: Fortress, 1994] 99-123, at 120).

$148 \mathrm{~J}$. Baird Callicott argues that the holistic land ethic is not a case of ecofascism but, instead, tends to supplement, not replace, the more venerable communitybased social ethics: "When holistic environment-oriented duties are in conflict with individualistic human-oriented duties, and the holistic environmental interests at issue are significantly stronger than the individualistic human interests at issue, the former take priority" (Beyond the Land Ethic 76). For a full explanation, see his chapter 4, "Holistic Environmental Ethics and the Problem of Ecofascism" 59-76.

${ }^{149}$ A detailed discussion of prudent environmental decision-making can be found in my "The Virtuous Cooperator" (see above n. 35). 
process out of which all entities have emerged. They should also discover and value the innate goodness of the various species and other natural entities, their interests and their needs to survive in the world, their instrumental relationship to one another, and the unique contributions they make to their shared ecological systems. And, faith-filled people should value the functioning of ecological systems and the biosphere to achieve their common good-their sustainability-now and in the future. Attention to these principles drawn from the Christian theological tradition should aid in restraining the ongoing degradation of Earth.

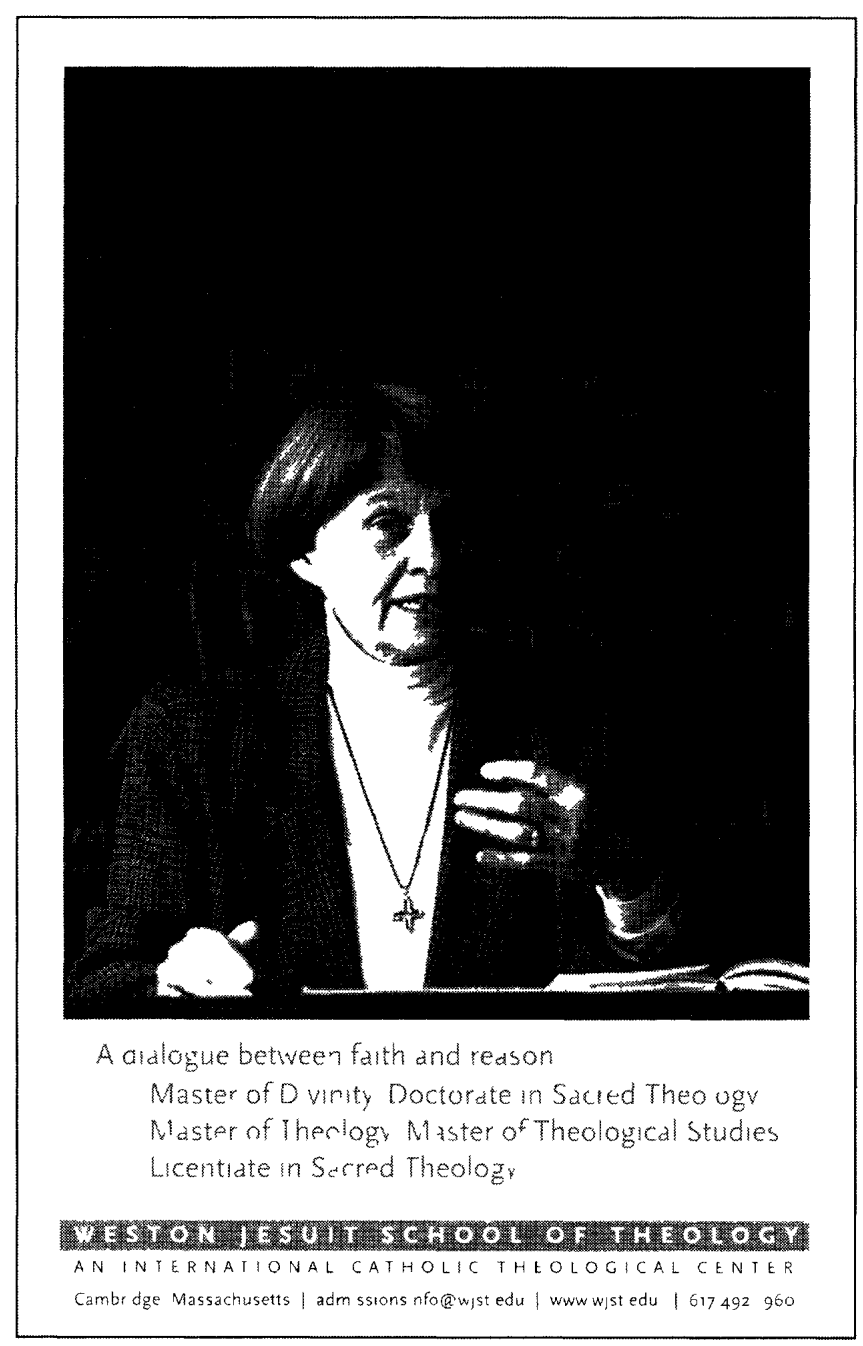




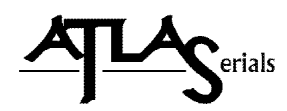

Copyright and Use:

As an ATLAS user, you may print, download, or send articles for individual use according to fair use as defined by U.S. and international copyright law and as otherwise authorized under your respective ATLAS subscriber agreement.

No content may be copied or emailed to multiple sites or publicly posted without the copyright holder(s)' express written permission. Any use, decompiling, reproduction, or distribution of this journal in excess of fair use provisions may be a violation of copyright law.

This journal is made available to you through the ATLAS collection with permission from the copyright holder(s). The copyright holder for an entire issue of a journal typically is the journal owner, who also may own the copyright in each article. However, for certain articles, the author of the article may maintain the copyright in the article. Please contact the copyright holder(s) to request permission to use an article or specific work for any use not covered by the fair use provisions of the copyright laws or covered by your respective ATLAS subscriber agreement. For information regarding the copyright holder(s), please refer to the copyright information in the journal, if available, or contact ATLA to request contact information for the copyright holder(s).

About ATLAS:

The ATLA Serials (ATLAS $®)$ collection contains electronic versions of previously published religion and theology journals reproduced with permission. The ATLAS collection is owned and managed by the American Theological Library Association (ATLA) and received initial funding from Lilly Endowment Inc.

The design and final form of this electronic document is the property of the American Theological Library Association. 